\title{
THE ROLE OF E-LEARNING INFRASTRUCTURE AND COGNITIVE COMPETENCE IN DISTANCE LEARNING EFFECTIVENESS DURING THE COVID-19 PANDEMIC
}

\author{
Askar Garad*, Abdullah M. Al-Ansi, Ika Nurul Qamari \\ Universitas Muhammadiyah Yogyakarta, Indonesia \\ *e-mail: askargarad@umy.ac.id
}

\begin{abstract}
Covid-19 has led to the closure of educational institutions around the world and turned formal learning into distance learning. This study aims to investigate the effect of e-learning infrastructure and individual's knowledge and competence on distance learning during the Covid-19 pandemic outbreak in 2020. E-learning infrastructure and individual's cognitive competence were also used to determine the readiness of educational institutions in distance learning. The e-learning infrastructure includes Learning Management System (LMS), electronic devices, communication applications, and internet accessibility. Quantitative approach was used in this study with a sample of 324 participants from three major universities in Yogyakarta, Indonesia. Data were collected through online surveys. The descriptive statistical approach and one-layer regression analysis were used to examine the problems raised in this study. The results show that distance learning is positively influenced by e-learning infrastructure and the cognitive competence of the students, the faculty, and administrative staff. The results also point out the university's readiness level in adopting online learning based on their previous experience of using the learning system. Finally, the study proposes that in order to improve the e-learning process, there needs to be sufficient financial support from the government, whereas the universities are advised to conduct workshops and training, and to provide teleconferencing applications.
\end{abstract}

\section{Keywords: e-learning, cognitive competence, distance learning, Covid-19.}

\section{PERAN INFRASTRUKTUR E-LEARNING DAN KOMPETENSI KOGNITIF DALAM EFEKTIVITAS PEMBELAJARAN JARAK SELAMA PANDEMIK COVID-19}

\begin{abstract}
Abstrak: Covid-19 telah menyebabkan penutupan lembaga pendidikan di seluruh dunia dan mengubah pembelajaran formal menjadi pembelajaran jarak jauh. Penelitian ini bertujuan untuk mengetahui pengaruh infrastruktur e-learning, pengetahuan dan kompetensi individu terhadap pembelajaran jarak jauh pada saat wabah Covid-19 di tahun 2020. Infrastruktur e-learning dan kompetensi kognitif individu juga digunakan untuk mengetahui kesiapan institusi pendidikan dalam pembelajaran jarak jauh. Infrastruktur e-learning meliputi Learning Management System (LMS), perangkat elektronik, aplikasi komunikasi, dan aksesibilitas internet. Pendekatan kuantitatif digunakan dalam penelitian ini dengan sampel 324 responden dari tiga universitas besar di Yogyakarta, Indonesia. Data dikumpulkan dengan survei daring. Pendekatan statistik deskriptif dan analisis regresi satu lapis digunakan untuk memeriksa masalah yang diangkat dalam penelitian ini. Hasil penelitian menunjukkan bahwa pembelajaran jarak jauh dipengaruhi secara positif oleh infrastruktur e-learning dan kompetensi kognitif mahasiswa, dosen dan staf administrasi. Hasil juga menunjukkan tingkat kesiapan universitas untuk mengadopsi pembelajaran online tergantung pada pengalaman mereka sebelumnya dalam menggunakan sistem pembelajaran. Terakhir, studi ini menyertakan saran untuk meningkatkan proses e-learning, seperti dukungan keuangan pemerintah dan menyelenggarakan lokakarya, pelatihan, dan penyediaan aplikasi telekonferensi oleh universitas.
\end{abstract}

Kata Kunci: e-learning, kompetensi kognitif, pembelajaran jarak jauh, Covid-19.

\section{INTRODUCTION}

Recently, since the beginning of 2020 , many countries around the world have been facing a global pandemic that has changed the traditional learning completely to distance learning. At
March 2020, Covid-19 was announced as an international pandemic by WHO (WHO, 2020). Outbreak of the virus forced educational institutions to stop traditional learning and start complete online learning. A quick response has 
been made by some educational institutions to move to online-learning while many others are still struggling to adopt the online learning as a solution for this problem.

Even though some universities around the world have adopted e-learning during last years, readiness for full transition was not expected. Sudden transforming to distance learning forced educational institutions to adopt online learning depending on the e-learning infrastructure of universities and cognitive competence of students, lecturers and staff. These two factors are significant to accomplish this task. Some of studies considered e-learning infrastructure as hardware and software (Gladun, Rogushina, Garc1'a-Sanchez, Martínez-Béjar, \& FernándezBreis, 2009; Wang, Peng, Huang, Hou, \& Wang, 2008; Zhong-Ping \& Hui-Cheng, 2004).

Although, there is no easy way to define the boundaries of e-learning, infrastructure of e-learning, this study includes e-learning system, electronic devices, communicating applications and internet access. Infrastructure of e-learning in related universities is not included due to breakout of Covid-19 and disability of attendance physically to campus. Other studies focused on the impact of ICT including the infrastructure on e-learning (Al-Ansi, Suprayogo, \& Abidin, 2019; Du, Fu, Zhao, Liu, \& Liu, 2013; Lee, Hsieh, \& Hsu, 2011) and resulted that ICT has positive and significant impact on e-learning process. This study emphasizes the importance of e-learning infrastructure for distance learning as compulsory need during outbreak of Covid-19 pandemic which led to ending up traditional learning totally.

E-learning has become necessary and critical for educational institution to survive. Effective e-learning system allows students and lecturers to interact quickly and easily. Since the beginning of the 21 th century many of e-learning systems have been implementing by educational institutions. This development was as a result of the technology development and innovation but it didn't replace the traditional learning. Furthermore, study by Divayana, (2017) which examines the implementation of e-learning faces several problems, including 1) e-learning planning is not optimal; 2) Students and lecturers are not familiar with using e-learning in the learning process; 3) Supporting facilities for e-learning are still limited; 4) Existence of e-learning has not been well socialized. It seems important that a culture of knowledge sharing and socialization about e-learning needs to be considered so that implementation can be well realized (Meylasari \& Qamari, 2017).

During Covid-19 pandemic, e-learning have already replaced traditional learning totally resulting many problems related to lack of effective infrastructure and human expertise. To remain competitive in today's tight labor market, organizations and companies including universities are employing advances in technology to train staffs more quickly, more effectively, and at less expense than the past (Urdan \& Weggen, 2000).

Designing and implementing of e-learning systems have been conducting by educational institutions continuously. Improving these systems depends on these institutions and their abilities to adopt new technologies and innovations. Some of studies of designing and implementing these systems have conducted by researchers. Interactive system for e-learning model were improved to deliver better lectures and contents to the students studying in the remote areas, and hence to improve the quality of education and interest. These systems include a dedicated educational satellite. The satellite is responsible to distribute the e-learning contents to the universities connected to it (Siddiqui \& Masud, 2012).

Introducing improved e-learning system allows upload of learning materials online and give room for one-on-one interaction with the lecturer by creating an avenue for the students to ask questions and get their answers online (Buhari \& Roko, 2017). Electrical devices and applications are also known as hardware and software. Personal notebooks and cellphones are the most useable device in e-learning in addition to PCs and tablets. Increasing development in technology reflects the remarkable usage of electronic devices in higher education. Using Technology devices in e-learning is significant especially in higher education related to high competence of students and complexity of study in this level (Al-Ansi et al., 2019). Transforming knowledge of e-learning such as video, audio, text, images and data are represented through effective electronic devices. PCs, Notebooks, Cellphones and Tablets are the sufficient tools for e-learning. 
The other role to conduct online learning depends on the ability of students and lecturers to use e-learning systems and applications. Recent studies in the field of education have examined the application of technology to support and increase motivation in the classroom (Serio, Ibáñez, \& Kloos, 2013; Huitt, 2011; Taran, 2005). These studies have concluded that students who have an incentive to learn are more likely to engage, persevere, and make an effort to complete assignments than students who are not motivated. Although learning is a complex process that cannot be understood simply by analyzing human responses to the characteristics of technology, previous research has shown that certain techniques can be used to enhance student motivation (Serio et al., 2013). Previous experience for students and lecturers helped them to adopt e-learning quickly.

The aim of this study is to measure the impact of e-learning infrastructure and individual's competence on distance learning during the pandemic in addition to determining the readiness of universities to adopt online learning during the outbreak of Covid-19. The reason of choosing distance learning is due to the Covid-19 pandemic where traditional learning has been changed to distance learning. Three educational institutions in Yogyakarta, Indonesia were chosen to conduct this study. Because these three universities have adopted online learning as a solution to overcome the problem of outbreak this virus. The influence of e-learning structure and cognitive competence of individuals on distance learning is critical due to importance of these two factors in accomplishment of distance learning (Karim \& Hashim, 2004; Chow \& Croxton, 2017; Teo, Kim, \& Jiang, 2020).

Distance learning in this study includes learning through learning management system (LMS) and applications. Effective distance learning depends on e-learning infrastructure and cognitive competence (Pokrovskaya, Lychkovskaya, \& Molodtsova, 2020; Morze, Vorotnykova, \& Makhachashvili, 2017) of students, lecturers and administration staff. Readiness of educational institutions was illustrated by effective of e-learning systems or LMS, electronic devices, communicational applications and internet accessibility in addition to ability and knowledge of both students and lecturers to use technologies and learning applications.

\section{METHODS \\ Research Approach}

This study was conducted by using descriptive statistic method and regression analysis which is categorized under quantitative approach. Based on the objectives of study which included e-learning infrastructure, individual's cognitive competence and distance learning, questionnaires were structured in three different categories. E-learning infrastructure included four indicators which are effectiveness of e-learning system, electronic device, communication applications and internet accessibility. Questionnaires were distributed online in three universities in Yogyakarta city, Indonesia.

\section{Participants}

A sample of 324 participants were accepted after review. Strata sampling technique included three categories: students, lectures and staff and sampling was randomly between groups. Characteristics of sample are showed in the Table 1. Choosing these three universities was based on their quick response to changing of traditional learning to distance learning in short time (two weeks). Questionnaires were distributed during the first semester of pandemic (April- even semester). Demographics of sample are illustrated based on university, gender and academic status.

Table 1. Characteristics of Sample

\begin{tabular}{lcc}
$\begin{array}{l}\text { Demographic of } \\
\text { Sample }\end{array}$ & $\begin{array}{c}\text { Number of } \\
\text { Sample }(\boldsymbol{N})\end{array}$ & $\begin{array}{c}\text { Percentage } \\
(\%)\end{array}$ \\
\hline Total & 324 & 100 \\
University: & & \\
$\quad$ University1 & 151 & $(46.6)$ \\
$\quad$ University2 & 92 & $(28.4)$ \\
$\quad$ University3 & 81 & $(25)$ \\
Gender: & & \\
$\quad$ Male & 142 & $(43.8)$ \\
$\quad$ Female & 182 & $(56.2)$ \\
Status: & & \\
$\quad$ Student & 243 & $(75)$ \\
$\quad$ Lecturer & 54 & $(16.6)$ \\
$\quad$ Staff & 27 & $(8.4)$ \\
\hline
\end{tabular}




\section{Procedures and Instruments}

By using Google Drive, questionnaires were added based on the different variables of the study. Link of questionnaire was distributed between selected sample of students and guidelines were provided by researchers. Instruments of e-learning infrastructure were e-learning system effectiveness, electronical devices, applications and internet accessibility. Each instrument includes five items (Questions). A sample of 20 expertise, lecturers, students and staff were chosen to conduct the validity of the questions. The respondent's answers showed that Cronbach alpha was .789 which shows the testing tool is reliable while some questions were modified again to ensure the validity of research instruments (questionnaires are included in appendixes of this research). While individual's cognitive competence and distance learning was determined by five and six items respectively. Items of questionnaire were developed based on previous studies in the field including Gable, Sedera, \& Chan (2008) infrastructure of e-learning and Al-Ansi et al. (2019) using ICT in learning and Ehlers (2011) cognitive competence and distance learning (Gable et al., 2008; AlAnsi et al., 2019; Ehlers, 2011).

\section{Data Collection and Analysis Techniques}

Data was collected by online questionnaires. Questions were closed and answers were rating between (1-5). Items were measured by using Likert scale 5 balanced (strongly agree, agree, normal, disagree and strongly disagree). Analysis was carried out through quantitative study of the data by using descriptive statistics and regression analysis. Descriptive statistics analysis using SPSS (25) includes mean and standard deviation to describe e-learning infrastructure and cognitive competence in three higher educational institutions. In addition, correlation and regression analysis to measure the influence of e-learning infrastructure and cognitive competence on distance learning. Regression analysis included one-layer test to measure the direct impact e-learning infrastructure and individuals' cognitive competences on distance learning effectiveness.

\section{FINDINGS AND DISCUSSION}

The purpose of presenting descriptive statistics of e-learning infrastructure factors and cognitive competences of individuals is to understand the role of every factor in implementing and supporting distance learning effectiveness and to measure the readiness of universities of adopting e-learning as solution during the outbreak of Covid-19 pandemic.

\section{Findings}

Effectiveness of Distance learning in this study was determined by e-learning infrastructure and cognitive competences of students, lecturers and staff of using e-learning systems and applications. Descriptive statistics of both variables are showed in Table 2. This part explains the ability of universities to adopt e-learning based on the e-learning infrastructure elements and individuals' cognitive competence.

Table 2. Descriptive Statistics of e-learning Infrastructure

\begin{tabular}{|c|c|c|c|}
\hline No. & $\begin{array}{l}\text { Indicators } \\
\text { of e-learning } \\
\text { Infrastructure }\end{array}$ & Mean & Std. Dev \\
\hline 1. & $\begin{array}{l}\text { Effective e-learning } \\
\text { system }\end{array}$ & 3.51 & 1.04 \\
\hline 2. & Electronic devices & 3.72 & .90 \\
\hline 3. & $\begin{array}{l}\text { Communication } \\
\text { applications }\end{array}$ & 3.36 & .97 \\
\hline 4. & Internet accessibility & 3.08 & 1.06 \\
\hline & Total & 3.42 & .99 \\
\hline
\end{tabular}

The frequencies and percentages of every item used in the survey are explained in Table 2. For e-learning infrastructure, instruments include effective e-learning systems, electronic devices, online applications and internet accessibility. Every instrument includes five items. These results showed that e-learning system was useful for distance learning and enabled respondents to accomplish their tasks better. Most of respondents were using laptops, Cellphones and PCs to attend online classes. These results showed that these devices were compatible with common browsers and easy to use for e-learning. Quality and effectiveness of electronical device was appropriate enough for learning online. High percentage of agreement showed the significance of electronic device in e-learning.

Communicating applications played important role in face-to-face e-learning. Some 
of these used application was Zoom, Microsoft Teams, Cisco WebEx, Google Hang Outs and Webinar. These results showed that using video call (conferencing Videos applications) is easy during online learning classes. In addition to universities support to use these applications, respondents think that video call applications are appropriate method for conducting online classes. Students can interact with lecturers and classmates easily during using e-learning applications. In addition to video call applications, students, lecturers and staff use social media application to communicate, send and receive educational materials. Internet accessibility is also important to conduct online classes.

In addition, items of survey included important questions about the availability of internet, coverage, speed and cost of internet. This result explained some problems in availability of internet and some problems related to coverage, speed and high cost. Although universities and government represented by telecommunication sector in the country have supported the e-learning process, the problem of coverage, speed and cost is continued.

Cognitive competences or abilities of using e-learning systems, devices and applications is significant to describe the readiness of related universities for e-learning. Using e-learning system is known previously by students, lecturers and staff while using video call applications (conferencing) was the first time for all of them. This result explains the good knowledge of participants of using e-learning system (see Table 3). In addition, previous knowledge of e-learning system and using applications in both laptop and cellphone as part of learning process enabled students and lecturers to switch quickly to fully online learning. Doing assignments were done by using laptops and university was equipped with projectors. Students and lecturers usually use communication application all period of studying.

Distance learning indicators are explained in the Table 4. Six items were chosen to determine the satisfaction of students, lecturers and staff of all process of distance learning. These items include willingness of students and lecturer to communicate, ability to manage classes and accomplish assignments online, necessity of face-to-face communication, difference of learning at classroom and home, motivation of learning online and level of difficulty of online learning.

Table 3. Descriptive Statistics of Cognitive Competence

\begin{tabular}{lcc}
\hline No. Items of Cognitive & Mean & $\begin{array}{l}\text { Std. } \\
\text { Competence }\end{array}$ \\
\hline 1. $\begin{array}{l}\text { Pervious knowledge of } \\
\text { online learning }\end{array}$ & 3.46 & .912 \\
2. $\begin{array}{l}\text { Skills to use e-learning } \\
\text { systems }\end{array}$ & 3.51 & .892 \\
$\begin{array}{l}\text { 3. } \begin{array}{l}\text { Sufficient computer } \\
\text { experience }\end{array} \\
\begin{array}{l}\text { Ability to communicate } \\
\text { and interact }\end{array}\end{array}$ & 3.59 & .880 \\
$\begin{array}{l}\text { Access to online } \\
\text { materials }\end{array}$ & 3.63 & .940 \\
\hline Total & 3.51 & .899 \\
\hline
\end{tabular}

Table 4. Descriptive Statistics of Distance Learning

\begin{tabular}{llc}
\hline No. $\begin{array}{l}\text { Items of Distance } \\
\text { Learning }\end{array}$ & Mean & Std. Dev \\
\hline 1. Actively communicating & 2.94 & 1.135 \\
2. Managing time & 3.19 & 1.098 \\
3. Direct contacting and & 3.33 & 1.177 \\
$\begin{array}{l}\text { reacting } \\
\text { 4. Online learning } \\
\text { comfortability }\end{array}$ & 2.86 & 1.146 \\
$\begin{array}{l}\text { 5otivating and self- } \\
\text { estimation }\end{array}$ & 3.09 & 1.137 \\
$\begin{array}{l}\text { Complete classes } \\
\text { availability }\end{array}$ & 3.22 & 1.100 \\
\hline & & \\
\hline
\end{tabular}

The result of descriptive statistics shows good acceptance of distance learning between students, lecturers and staff of educational institutions. Willingness of students and lecturer to communicate through e-learning systems and applications was moderate level related to some problems in communications applications. Ability to manage classes and accomplish assignments online is good and appropriate while necessity of face-to-face communication is significant and more effective to learn. Learning online is effective as learning in classrooms and students have more motivation of learning online. Sudden transforming from ordinary classes to online class impact on some students and lecturer to adopt online classes quickly. 
Finally, most students believe that a complete course can be given by the Internet without difficulties.

Role of e-Learning Infrastructure and Cognitive Competence in Distance Learning

Before testing the role of e-learning infrastructure and cognitive competence in distance learning, researcher have tested the correlation between variables and instruments with each other. Correlation analysis was conducted to explain the relationship between these instruments and variables to ensure there is no problem to conduct regreation analysis.

Correlation between infrastructure e-learning, cognitive competence and distance learning is positive and significant with .625 and .571 respectively (see Table 5). Instruments of e-learning infrastructure are correlated and acceptable as well. These results show a high significant level with $p$ less than .05 of confidence $(p<.05)$ as Table 6.

Correlational research observes and measures patterns between 4 variables included in infrastructure e-learning which are e-learning systems, Devices, Applications, and Internet Access. Correlational research reveals a positive relationship between the aforementioned variables.

In this research, the strength of a correlation between quantitative variables is measured using a Pearson's Correlation Coefficient (or Pearson's $r$ ). A positive correlation is indicated by a value of 1.0, a perfect negative correlation is indicated by a value of -1.0 while zero correlation is indicated by a value of .0 .

$R$-squared coefficient for this multi-variant regression mode (e-learning infrastructure and cognitive competence as independent variables and distance learning as dependent variable) is .562 , meaning that there is $56 \%$ of distance learning variation explained by dependent variables.

Examining Table 7, the results show that: there is a positive impact with $(\beta=.349)$ and significant with $(p<.000)$ of e-learning infrastructure on distance learning. Also, there is a positive impact with $(\beta=.355)$ and significant with $(p<.000)$ of individuals cognitive competence on distance learning while using e-learning systems and applications. After breakout of Covid-19, distance learning depends on these two variables completely. These results explain that, readiness of universities for online learning during Covid-19 was good regardless some problems related to internet access.

Table 5. Correlation among Variables

\begin{tabular}{lccc}
\hline & Distance Learning & e-learning Infrastructure & Cognitive Competence \\
\hline Pearson correlation & 1 & $.625^{* *}$ & $.571^{* *}$ \\
Sig. (2-tailed) & & .000 & .000 \\
$N$ & 324 & 324 & 324 \\
\hline
\end{tabular}

Table 6. Correlation between Instruments of Infrastructure

\begin{tabular}{lcccc}
\hline Infrastructure & e-learning System & Devices & Applications & Internet Access \\
\hline e-learning system & 1.000 & .569 & .580 & .554 \\
Devices & & 1.000 & .610 & .614 \\
Applications & & & 1.000 & .613 \\
Internet access & & & & 1.000 \\
\hline
\end{tabular}

Table 7. Impact of e-learning Infrastructure and Cognitive Competence on Distance Learning Effectiveness

\begin{tabular}{|c|c|c|c|c|c|c|c|}
\hline \multicolumn{8}{|c|}{$\begin{array}{c}\text { Coefficients } \\
\end{array}$} \\
\hline \multirow{2}{*}{ Model } & \multicolumn{2}{|c|}{$\begin{array}{l}\text { Unstandardized } \\
\text { Coefficients }\end{array}$} & \multirow{2}{*}{$\begin{array}{c}\begin{array}{c}\text { Standardized } \\
\text { Coefficients }\end{array} \\
\text { Beta }\end{array}$} & \multirow[t]{2}{*}{$t$} & \multirow[t]{2}{*}{ Sig. } & \multirow[t]{2}{*}{$\boldsymbol{R}$} & \multirow[t]{2}{*}{$R$ Square } \\
\hline & $B$ & Std. Error & & & & & \\
\hline (Constant) & 1.095 & 1.235 & & .887 & .376 & & \\
\hline Infrastructure e-learning & .560 & .089 & .349 & 6.322 & .000 & .750 & .562 \\
\hline Cognitive competence & .450 & .070 & .355 & 6.419 & .000 & & \\
\hline
\end{tabular}




\section{Discussion}

This study discusses two main issues related to learning process during covid-19 pandemic in 2020. The first one is about the ability of the universities to adopt online learning during the pandemic while the second one is about the influence of e-learning infrastructure and cognitive competence of individuals as appropriate determinants of distance learning. Ability of universities during outbreak of Covid-19 in 2020 to adopt distance learning as solution for this problem was described and analyzed by infrastructure of e-learning and cognitive competence of students, lecturers and staff to use this technology for e-learning. Selecting three top universities in Yogyakarta city in Indonesia was related to the high ranking for these universities in local and international level. Based on the universities ranking index 2020 (UniRank, 2020), universities, as the object under study, have ranked number 1, 6 and 15 in Indonesia respectively. Three universities are located at the same city and have adopted e-learning during Covid-19 pandemic.

E-learning infrastructure was measured by four indicators. Mean of each indicator was e-learning system (3.51), electronic devices (3.71), applications (3.36) and internet access (3.08). There is no high covariance between these means where the electronic devices were higher and internet access less than other indicators. This shows that personal laptops and cellphones were available for all students and lecturers (self-provided) and internet access was limited related to some problems in the infrastructure of education in the country. Cognitive knowledge was also at the same level of other infrastructure indicators with mean (3.51). Descriptive statistic of distance learning was intermediate with mean of 3.10 out of 5. Many studies have supported the same result (Bennett, 2010; Ehlers, 2011; Schulze, 2016; Wang et al., 2008), with little differences where mean in the previous studies was higher related to that distance learning was optional whereas in this study became compulsory.

Before the covid-19 pandemic, studying influence of e-learning infrastructure and cognitive competence of individuals to use e-learning approaches is not sufficient due to the traditional learning where students and lecturers have to come campus every day. Physical attendance was important and classes were conducted face to face. Complete transforming to distance learning made this study meaningful and important. Infrastructure of normal learning process changes to e-learning infrastructure where no campus, buildings, laps and physical attendance.

In another hand, ability of individuals to use technology such as conferencing applications, using LMS, receiving and sending materials online and doing many assignments simultaneously was the key to include all these elements under the individual's cognitive competence. The second part of this study discussed the influence of e-learning infrastructure and cognitive competence of individuals on the distance learning. Results showed that there is a positive and significant impact of e-learning infrastructure and cognitive competence on distance learning with $(\beta=.349$ and $\beta=.355)$ respectively. These results also similar to previous studies of impact ICT on Learning process (Gable et al., 2008; Al-Ansi et al., 2019) with taking into consideration differences in full transforming to distance learning.

During Covid-19 crisis, universities introduced some video call applications such as Zoom, Cisco, Microsoft Team, Hangouts and many other Web conferencing tools. Usage and benefits of using ICT applications is more effective in higher levels of education related to many factors such as: policies of learning, difference of abilities, capacity of absorption, specification of studies, extent of need and complexity (Al-Ansi et al., 2019). In addition, using social media is critical to conduct online classes and to communicate between learners and facilitators of distance learning.

Although the Internet penetration rate is only 53.7 percent, which is lower than many countries in the Asia Pacific region, Indonesia is one of the countries with the largest number of Internet users in the world, as of December 2017, 143.3 million (Statista, 2019a) of the country's total population of 260 million were active Internet users. Due to the prohibited content and the various restrictions on media freedom, Indonesia is ranked only partially free in the Freedom House Index 2018, which ranks countries according to the degree of Internet freedom, with 46 index points (Statista, 2019b). 
Speed of internet, Coverage and cost were determinants of effective internet accessibility in educational institutions. Role of government and universities as facilitators of e-learning process is significant towards effective distance learning. Internet access is important factor of e-learning infrastructure in this study in addition to hardware and software.

Communicating between students and educators through internet is critical to successful learning distance. Both students and educators have to be able to use technological device and applications. Successful distance learners are always self-trained, committed, effective and not afraid to defend themselves. Important aspects of self-management are motivation and possessing a learning strategy, which have a significant effect on learning results (Wang et al., 2008) and transformative learning (Qamari, Ferdinand, Dwiatmadja, \& Yuniawan, 2020).

Instructor feedback sets clear expectations, provides encouragement for the student and identifies areas of improvement. Instructors play a significant role by setting high academic standards and providing quick and clear feedback that includes useful examples (Schulze, 2016). Cognitive competence in using social media, educational applications and electronic devices is the core of distance learning. Without good knowledge of these technologies, distance learning will remain difficult and unreachable. Some previous studies investigated the characteristics of learners and effective distance education (Schrum \& Hong, 2002; Gibson, 2003). These studies concluded some of these characteristics such as a larger range of a more favorable cost / benefit ratio is essentially a greater possibility (for both facilitators and learners) because they believe in the possibility of allocating distance learning, at this level where it reaches uniqueness.

Distance learning is also known as e-learning, online learning or distance education, means existence of teachers and students in different environment out of campus. It includes using of various technological tools to facilitate communication between students and teachers during instruction process. Development of distance learning continued by development of technologies and internet. Revolutionary change in technologies and social media at the beginning of the twenty-first century led to interactive and web-based learning (Kiryakova, 2009; Fachrunnisa, Adhiatma, \& Tjahjono, 2020; Suprijo, Tjahjono, Muafi, \& Prajogo, 2019).

Many previous studies confirmed that distance learning should include important factors to accomplish this mission (Bennett, 2010). These studies included important features of distance learning such as user identification and user management, preparation of course contents, course management, student start-up programs, homework and project preparation/ preparation, test preparation, monitoring and analyzing student behavior, determining student success status, creating and managing an interactive communication environment. This study investigates distance learning based on e-learning infrastructure and cognitive competences of students and lecturers in addition to administration staff of related universities.

\section{CONCLUSION}

Readiness of three universities to adopt distance learning (online learning during Covid-19) was proper and significant but still need to be improved. Conducting distance learning had an immediate response during two weeks. E-learning system was implemented previously and electronic devices such as laptops and cellphones were provided by individuals in addition to university's support for staff. These results are unique due to completely transforming of traditional learning to e-learning because they explain the effectiveness of distance learning during Covid-19 pandemic. In addition, these results measure the readiness of universities and their ability to cope this problem depending on distance learning and its features and innovative approaches.

According to the regression analysis, the results also revealed that e-learning infrastructure and individuals' cognitive competence have positive and significant impact on distance learning. In fact, after Covid-19, the educational institutions have completely depended on e-learning infrastructure tools such as internet, electronic device, applications and LMSs in addition to the previous knowledge of students, lecturers and staff of distance learning.

Finally, there is need for more efforts by government and educational institutions to improve the distance learning. Investing in the e-learning infrastructure, supporting students and 
lecturers with needed materials, workshops and training is important to increase their knowledge to adopt online learning. Facilitating software and hardware of e-learning infrastructure is the main factor to successful education process.

\section{REFERENCES}

Al-Ansi, A. M., Suprayogo, I., \& Abidin, M. (2019). Impact of information and communication technology (ICT) on different settings of learning process in developing countries. Science and Technology, 9(2), 19-28. http://article. sapub.org/10.5923.j.scit.20190902.01. html.

Bennett, K. W. (2010). A case study of perceptions of students, teachers, and administrators on distance learning and music education in Newfoundland and Labrador: A constructivist perspective. (Master thesis, Memorial University of Newfoundland). https://research.library. mun.ca/8703/.

Buhari, B. A. \& Roko, A. (2017). An improved e-learning system. Saudi Journal of Engineering and Technology, 2(2), 114118. http://scholarsmepub.com/sjeat-22/.

Chow, A. S., \& Croxton, R. A. (2017). Designing a responsive e-learning infrastructure: Systemic change in higher education. American Journal of Distance Education, 31(1), 20-42. https://doi.org/10.1080/089 23647.2017.1262733.

Divayana, D. G. H. (2017). Evaluasi pemanfaatan e-learning menggunakan model CSEUCLA. [Evaluation of e-learning utilization using CSE-UCLA model]. Cakrawala Pendidikan, 36(2), 280-289. https://doi.org/10.21831/cp.v36i2.12853.

Du, Z., Fu, X., Zhao, C., Liu, Q., \& Liu, T. (2013). Interactive and collaborative e-learning platform with integrated social software and learning management system. In W. Lu, G. Cai, W. Liu, W. Xing (Eds.). Proceedings of the 2012 international conference on information technology and software engineering. Berlin: Springer, pp. 11-18. https://doi.org/10.1007/978-3-
642-34531-9 2.

Ehlers, U. D. (2011). Quality in e-learning from a learner's perspective. European Journal of Open, Distance and E-Learning. https:// doi.org/10.4000/dms.2707.

Fachrunnisa, O., Adhiatma, A., \& Tjahjono, H. K. (2020). Collective engagement and spiritual wellbeing in knowledge based community: A conceptual model. In L. Barolli, F. Hussain, \& M. Ikeda (Eds.). Complex, intelligent, and software intensive systems, Proceedings of the 13th International Conference on Complex, Intelligent, and Software Intensive Systems (CISIS-2019). Switzerland, AG: Springer, pp. 899-906. https://doi.org/10.1007/9783-030-22354-0 83.

Gable, G. G., Sedera, D., \& Chan, T. (2008). Re-conceptualizing information system success: The IS-impact measurement model. Journal of the Association for Information Systems, 9(7), 377-408. https://doi.org/10.17705/1jais.00164.

Gibson, C. C. (2003). Learners and learning: The need for theory. In M. G. Moore \& W. G. Anderson (Eds.). Handbook of distance education. Mahwah, NJ: Lawrence Erlbaum Associates, pp. 147-160.

Gladun, A., Rogushina, J., Garc1'a-Sanchez, F., Martínez-Béjar, R., \& FernándezBreis, J. T. (2009). An application of intelligent techniques and semantic web technologies in e-learning environments. Expert Systems with Applications, 36(2), 1922-1931. $\quad$ https://doi.org/10.1016/j. eswa.2007.12.019.

Huitt, W. (2011). Motivation to learn: An overview. Educational psychology interactive. Valdosta, GA: Valdosta State University. http://chiron.valdosta.edu/ whuitt/col/motivation/motivate.html.

Karim,M.R.,\&Hashim,Y.(2004). Theexperience of the e-learning implementation at the Universiti Pendidikan Sultan Idris, Malaysia. Malaysian Online Journal of Instructional Technology (MOJIT), 1(1), 50-59. http://ldms.oum.edu.my/oumlib/ 
sites/default/files/file attachments/odlresources/4323/experience-upsi.pdf.

Kiryakova, G. (2009). Review of distance education. Trakia Journal of Sciences, 7(3), 29-34. http://tru.uni-sz.bg/tsj/.

Lee, Y.-H., Hsieh, Y.-C., \& Hsu, C.-N. (2011). Adding innovation diffusion theory to the technology acceptance model: Supporting employees' intensions to use e-learning systems. Journal of Educational Technology \& Society, 14(4), 124-137. https://www.jstor.org/stable/ jeductechsoci.14.4.124.

Meylasari, U. S., \& Qamari, I. N. (2017). Faktorfaktor yang mempengaruhi knowledge sharing dalam implementasi e learning. Jurnal Manajemen Bisnis, 8(2), 238-263. https://journal.umy.ac.id/index.php/mb/ article/view/3949.

Morze, N., Vorotnykova, I., \& Makhachashvili, R. (2017). E-learning specialists training for IT infrastructure of an educational institution management. International Journal of Research in E-learning, 3(1), 11-26. https://www.ceeol.com/search/ article-detail?id=739874.

Pokrovskaya, E. M., Lychkovskaya, L. E., \& Molodtsova, V. A. (2020). Foreign language e-learning course as an element of city infrastructure for cognitive enhancement for the third age people. In Z. Anikina (Eds.). Integrating engineering education and humanities for global intercultural perspectives (Lecture Notes in Networks and Systems, vol 131). Switzerland, AG: Springer, Cham, pp. 3-10. https://doi.org/10.1007/978-3-03047415-7 1.

Qamari, I. N., Ferdinand, A. T., Dwiatmadja, C., \& Yuniawan, A. (2020). Transformative interaction capability: the mediating role between quality of work life and teamwork performance. International Journal of Quality and Service Sciences, 12(2), 133-148. https://doi.org/10.1108/ IJQSS-01-2019-0008.

Schrum, L., \& Hong, S. (2002). Dimensions and strategies for online success: Voices from experienced educators. Journal of Asynchronous Learning Networks, 6(1), 57-67. https://doi.org/10.24059/olj. v6i1.1872.

Schulze, S. (2016). Socializing postgraduate students to success in an open and distance learning environment. South African Journal of Higher Education, 30(4), 277290. https://doi.org/10.20853/30-4-578.

Serio, A. D., Ibáñez, M. B., \& Kloos, C. D. (2013). Impact of an augmented reality system on students' motivation for a visual art course. Computers and Education, 68(C), 586-596. https://doi.org/10.1016/j. compedu.2012.03.002.

Siddiqui, A. T., \& Masud, M. (2012). An e-learning system for quality education. International Journal of Computer Science Issues, 9(4), 375-380-9. https://www.ijcsi. org/papers/IJCSI-9-4-1-375-380.pdf.

Statista. (2019a, June). Countries with the highest number of internet users as of December 2019. https://www.statista. $\mathrm{com} / \mathrm{statistics} / 262966 /$ number-ofinternet-users-in-selected-countries/.

Statista. (2019b, October). Degree of internet freedom in selected countries according to the Freedom House Index 2020. https:// www.statista.com/statistics/272533/ degree-of-internet-freedom-in-selectedcountries/.

Suprijo, S., Tjahjono, H. K., Muafi, M., \& Prajogo, W. (2019, 10-11 April). Innovation behavior and manager's performance based on local wisdom: Sustainable construction approach. Paper presented at the $33^{\text {rd }}$ International Business Information Management Association Conference, Granada, Spain.

Taran, C. (2005, 5-8 July). Motivation techniques in elearning. Paper presented at the Fifth IEEE International Conference on Advanced Learning Technologies, Kaohsiung, Taiwan. https://doi. org/10.1109/ICALT.2005.206. 
Teo, T. S. H., Kim, S. L., \& Jiang, L. (2020). E-learning implementation in South Korea: Integrating effectiveness and legitimacy perspectives. Information Systems Frontiers, 22(2), 511-528. https:// doi.org/10.1007/s10796-018-9874-3.

UniRank. (2020). Top universities in Indonesia 2021 indonesian university ranking. https://www.4icu.org/id/.

Urdan, T. A., \& Weggen, C. C. (2000). Corporate elearning: Exploring a new frontier. $\underline{\mathrm{http} / / /}$ papers.cumincad.org/data/works/att/2c7d. content.pdf.

WHO. (2020, 11 March). WHO DirectorGeneral's opening remarks at the media briefing on COVID-19. https://www. who.int/dg/speeches/detail/who-directorgeneral-s-opening-remarks-at-the-mediabriefing-on-covid-19---11-march-2020.

Wang, Y., Peng, H., Huang, R., Hou, Y., \& Wang, J. (2008). Characteristics of distance learners: Research on relationships of learning motivation, learning strategy, self-efficacy, attribution and learning results. Open Learning: The Journal of Open, Distance and e-Learning, 23(1), 17-28. https://doi. org/10.1080/02680510701815277.

Zhong-Ping, Z., \& Hui-Cheng, L. (2004). The development and exploring of e-learning system on campus network. Journal of Shanxi Teacher's University (Natural Science Edition), 18(1), 36-40. 